\title{
RECENZIÓ ÉBER MÁRK ÁRON “A CSEPP. A MAGYAR TÁRSADALOM OSZTÁLYSZERKEZETE” CÍMÜ KÖNYVÉRŐL
}

\section{A recenzió szerzője:}

Godó Irén

Debreceni Egyetem (Magyarország)

A szerző e-mail címe:

godo.iren@arts.unideb.hu
Lektorok:

Mező Katalin (PhD.)

Debreceni Egyetem, Magyarország

Godó Katalin

Debreceni Egyetem, Magyarország

Godó Irén (2021). Recenzió Éber Márk Áron “A csepp. A magyar társadalom osztályszerkezete” című könyvéről. Különleges Bánásmód, 7. (3). 115-119. DOI 10.18458/KB.2021.3.115

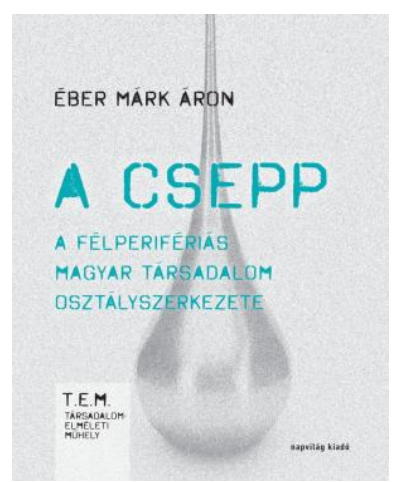

Jelen recenzió alapjául szolgáló mủ bibliográfiája:

Éber Márk Áron (2020): A csepp. A magyar félperifériás társadalom osztályszerkezete. [The drop. The class structure of the semi-peripheral Hungarian society] Napvilág Kiadó, Budapest. ISBN: 978-963-338-4527

Kép forrása: Libri.bu (URL: https:/ / www.libri.hu/konyv/eber mark aron.a-csepp.html Letöltés ideje: 2021. 05. 13.)

Kulcsszavak: magyar társadalom, osztályszerkezet, globális viszonyok, világrendszer-elemzés

Diszciplína: szociológia, közgazdaságtan

Keywords: hungarian society, class-structure, global relations, world-systems theory

Disciplines: sociology, economics

Éber Márk Áron “A csepp. A magyar félperifériás társadalom osztályszerkezete” címú könyve a Politikatörténeti Alapítvány Társadalomelméleti Múhelyében készült és a Nemzeti Kulturális Alap és a Politikatörténeti Alapítvány, illetve a Politikatörténeti Intézet támogatásával jelent meg 2020-ban a Napvilág Kiadó gondozásában.

Éber Márk Áron munkásságának középpontjában a magyar társadalom szerkezeti átalakulásának vizsgálata áll. A válaszokhoz vezetô út során globális összefüggéseket keres, s a magyar társadalom- és gazdaságpolitikai problémákat a globális gazdasági kapcsolatrendszerek és függőségek hálójába, illetve hazánknak a világrendszerben elfoglalt félperifériás helyzetébe ágyazva mutatja be. A szerző kutatói tevékenységét az ELTE Társadalomtudományi Karán belül a Szociálpolitikai Tanszék adjunktusaként végzi, ugyanakkor igazgatói feladatot lát el az ELTE Angelusz Róbert Társadalomtudományi 
Szakkollégiumában, s 2016 óta szerkesztője az Új Egyenlőség nevú online magazinnak is.

A 2020-ban megjelent könyv témája Éber munkásságának egyik kulcsfontosságú kérdését taglalja, jelesül a magyar társadalom osztályszerkezetét, illetve azt a folyamatot tárja fel, mely során az elérte mai állapotát. A könyv 284 oldal terjedelemben járja körül a kérdéskört, mely tekintve a tartalomjegyzékben szereplő címszavak nagy mennyiségét és a tárgyalt téma szerteágazó jellegét, lehetőséget ad a téma mély kifejtésére és a komplex mondanivaló megértésére. A címszavak már önmagukban véve beszédesek, éppen ezért a könyvben Éber is csak annyira részletezi ezeket, amennyire a lényeg megértéséhez szükségesnek találja.

A magyar társadalom osztályszerkezetének vizuális ábrázolására nemcsak Éber tesz kísérletet, pl. Kolosi Tamás korábban terhes babapiskótaként, majd piramisként jelenítette meg azt. A könyv borítóján szereplő cím (A csepp. A félperifériás magyar társadalom osztályszerkezete), miként a rajta megmutatkozó ábra sűrítetten összefoglalja a mondanivalót. Ami viszont a kíváncsiságot felkeltheti, inkább a miértek. A szerző 5 fejezeten keresztül kalauzol el bennünket a megértés útján. Társadalmi viszonyokat és kölcsönhatásokat, relációkat jelenít meg, vizsgál (osztályszerkezet, osztályhelyzetek, osztályviszonyok), hovatovább a magyar társadalmat is ezek mentén írja le, s a jelen állapotokat szintén ezekből vezeti le. A könyv az osztályviszonyok társadalmi termékének tekinti az egyént is, a munkát pedig folyamatként, viszonyként és termékként egyaránt értelmezi.

Az I. fejezetben többek között a tőke és a munka kapcsolatáról esik szó. Marx-i alapokra támaszkodva hangsúlyozásra kerül a kizsákmányoló és a kizsákmányolt függő viszonya, a tôkések uralma saját munkájukon kívül mások munkája felett, s a mások munkája révén elóállított termékek felett. De hogyan érvényes ez az elmélet a mai társadalomra? Arról már az első fejezetben sok minden kiderül. A bérmunka mellett a szerző munkának tekinti az informális, legálisan be nem jelentett munkát is. Miért olyan fontos ez ebben a fejezetben? Ahogy azt a szerző szemléletes példákon keresztül érzékelteti, számos a mindennapi élet gördülékeny múködéséhez hozzájáruló munkafolyamatok tartoznak ide. Például az elsősorban nők által végzett reproduktív munka, vagyis az otthoni informális munkavégzés (láthatatlan munka), amely hozzájárul a gazdaság eredményes működéséhez. A másik fontos formája az informális munkának Magyarországon a szürke- és feketemunka, mely a nyugateurópai országokhoz képest hazánkban jóval elterjedtebb. Jellemzően még a kedvezőbb osztályhelyzetben élőket sem annyi pénzért és olyan munkaidőben szokták bejelenteni a munkáltatók a magas adóterhek miatt, mint amennyiért és amenynyit ténylegesen dolgoznak, a legalsóbb osztályokban pedig a bejelentetlen feketemunka elterjedt, ami szociális helyzetüket, egzisztenciális biztonságukat még tovább rontja. Emiatt mindenképp szükségünk van a fentiek figyelembe vételével a munka átfogó komplex értelmezésére ahhoz, hogy valós képet kapjunk, s ezt nagyon helyesen felismerte a szerző munkája során.

Éber tudományos perspektívájának legfőbb pillére a világrendszer-elemzés. A könyv szerzője szerint globalizált világunkban az osztályszerkezet és a társadalmi struktúra mélyen beágyazódik a tôkés világrendszer struktúráiba, a globalizált kapitalizmus egyben globális függési rendszer is. Mind a kapitalizmus különféle válfajait vizsgáló irányzatoktól, mind pedig az államhatárok közé szúkülő módszertani nacionalizmustól élesen elhatárolja magát. Az élet újratermelésének folyamatait világszinten szerveződő, historikus kontextusba ágyazott, egyszerre társadalmi, gazdasági, kulturális, történeti és térbeli viszonyként értelmezi. Szerinte egyedül ez a komplex és életszagú megközelítés alkalmas arra, hogy ne az uralom hatékonyabbá tételére, hanem az uralmi viszonyok kritikai átvilágítására, s ezzel az emberi szenvedés mérséklésére kerüljön a fókusz a társadalomtudományban. 
A II. fejezet kulcstémája a beágyazottság. Miképp a viszonyokról és relációkról szó esett, a kapitalista múködésû világrendszerbe való beágyazottsága a helyi társadalmaknak tagadhatatlan tény, az ez elól való menekülést is csak nagyon kevés ember tudja megvalósítani.

A tôkés világrendszer, mint a tőkefelhalmozás globális rendszere az osztályviszonyok formálódására kétségkívül hatással van. A második fejezetben történelmi példákon keresztül kerülhetünk közelebb ennek megértéséhez, látva a napjainkig vezetô folyamatot is, nemcsak a tôkére vonatkozóan, hanem társadalmi, szerkezeti szinten is. Ennek a fejezetnek a fó mondanivalója a gazdaság és társadalom egymástól elválaszthatatlan kölcsönhatása a különféle történelmi események kontextusában. Megtudjuk, a magyar társadalom osztályszerkezete miként polarizálódott a globális (külső) és belső hatások következményeként, hogyan jutunk el a magyar társadalom társadalom-politikájában a Máté-hatásnak nevezett jelenséghez.

Máté evangéliumában találkozhatunk ezzel (Mt 13, 12): „Mert akinek van, annak adatik, és bövelkedik, akinek pedig nincs, attól az is elvétetik, amije van." Gyakorlatilag a gazdag tovább gazdagodik, a szegény pedig még szegényebbé válik.

Éber a III. fejezetben a helyi termelési viszonyokon és folyamatokon túl az ország globális beágyazottságára hívja a fel figyelmet. Hogy mi jellemző erre a beágyazottságra, azt három fó statisztikai adattal illusztrálja, amelyek vizuális megjelenítése is helyet kap a könyvben. A tőkés világrendszert és az osztályszerkezetet táblázat(ok) segítségével különíti el egymástól. A centrumországok és a perifériára szorult országok helyzete közti különbségekről úgy véli, hogy komoly érdekellentéteket hordoznak magukban. A fő konfliktusgóc az, hogy a perifériákon hasznosuló tôke a centrumtőkének alárendelten múködik. Éber nem tartja statikusnak a tőkés világrendszert, hanem változékonynak és konfliktusosnak tekinti az erő- viszonyait. A kapitalista világrendszer középosztályi pozíciói a centrumtársadalmakban tömörülnek leginkább, míg a perifériákon csak nagyon szúk réteg él olyan körülmények közt, ami alapján beleillene a centrum középosztályának keretei közé, ezért Magyarországon csak a középosztály eszményérôl beszélhetünk. A perifériákon lévő államok törekvései többnyire az ország egész társadalmának felzárkózási programjaként jelenik meg. A magyar társadalom osztályszerkezetének jellemzésére három osztályhelyzetet különít el (felső-uralkodó tőkésosztály, közvetítő helyzetben lévő osztályok, alsó-alávetett munkásosztályok).

A IV. fejezetben a csepp formájának miértjét ismerjük meg. Miként a borítón is megjelenik, felfelé és lefelé megnyúlt csepphez hasonlítja Magyarország társadalmilag, politikailag és kulturálisan tagolt (széthúzódó) osztályszerkezetét. A magyar társadalom alsó 2/3-a jelenti a csepp alsó, szélesebb részét, azaz belőlük van jóval több. A felsô része viszont felfelé nyúlt meg. A III. fejezet végén említett osztályokról részletesen beszél a szerző a könyv további részében.

Említést tesz a különféle erőforrásokról, ilyen a gazdasági-, a kulturális- és a társadalmi erőforrás. Ezen erőforrások elosztásának egyenlótlensége a globális struktúrákba ágyazott magyar társadalom osztályszerkezetében egyre inkább fokozódott. Beszél a megnyúlás és az osztályszerkezet széthúzódásának okairól is, illetve a társadalmi mobilitás esélyeirôl. Szerinte osztályhelyzetek igenis léteznek, erről olvashatunk bővebben a könyvben. A Szerző állításait a IV. fejezetben empirikus rétegződéskutatással támasztja alá, fény derül az osztályszerkezet széthúzódására, az osztályok polarizációjára, a felsőosztály viszonylagos eltávolodására.

Az utolsó fejezetben (V. fejezet) arról ír, hogy a magyar társadalom és osztályszerkezet alá van vetve az állam és a gazdasági szféra összefonódásának. Biztos jövedelemforrás és megélhetés hiján prekarizálódó léthelyzethez hasonlította Éber az alsó-alávetett munkásosztályok és a köztes, köz- 
vetítő osztályok helyzetét. Leírja, hogy a cigányság ma már nemcsak etnikum, hanem többletjelentést nyert, az alávetett osztályhelyzet szimbólumává is vált. A cigány-magyar megkülönböztetés a közmunka és a bérmunka, az informális és formális munkaerôpiaci pozíció, az ipari tartaléksereg és az ipari bérmunka, valamint a szubproletár és proletár helyzet osztálykülönbségeinek ad egyfajta leplező etnikai színezetet. Szerintem ez különösképp húen illusztrálja a romák számkivetett helyzetének osztály szintű vetületét is.

Szinte konklúziónak is beillik a könyv utolsó fejezetében helyet kapó gondolat, miszerint a magyar társadalom osztályszerkezetének elnyúló csepp alakkal leírható egyre fokozódó polarizációja nagyobbrészt a tôkés világrendszer polarizációjának, kisebb részt a magyar állam beavatkozásának eredménye.

\section{Összefoglalás, lezárás}

A könyv végül tartalmaz összefoglalót is, mely felöleli az összes fejezet együttes mondanivalóját. A magyar társadalom osztálystruktúráját egy komplex viszonyrendszer hálójába helyezte a szerző. Emellett értelmezhetô keretet ad a munkaerőpiaci migráció vizsgálatának és irányának is.

Rendszerkritikai élű megállapításnak tartom, hogy a kapitalizmusban az élet és munkaerô újratermelése alá van vetve a tőkefelhalmozás logikájának, ami még erôteljesebben jelentkezik a félperiférián vagy gazdasági válságok idején. Mindez a létfontosságú reproduktív munkák társadalmilag káros hatásokkal járó, indokolatlan leértékelésétól kezdve a családok szétszakadásáig és a mindig dolgozó, gyerekeiktől elidegenedő szülókig számos válságjelenség forrása lehet. A könyvben központi szerepet kapott a középosztály problematikája, illetve annak a magyar társadalomszerkezetben elfoglalt pozíciója is.
A társadalmi polarizáció tragikus mértéke egy mázsás súllyal ránk nehezedő téma, amit önmagában sem könnyú feldolgozni. Leginkább azzal traumatikus szembesülni, hogy a magyar osztályszerkezet messzemenôkig nem egy lokálisan kialakult és lokálisan kezelhetô struktúra. Ehelyett monolitikus és hegemón világrendszerbe ágyazódó függőségi viszonyok hálózata köti gúsba. Az államhatárokon átívelő, az egyes államok szuverén hatalmával sem alakítható gazdasági folyamatok bonyolult, árnyalt oksági összefüggéseinek rengetegében keresendőek a válaszok és megoldások.

A szerző a világrendszer jelentette hatalmas és akár legyőzhetetlennek ható erők ellenére is optimistán zárja a könyvet, kimondja ugyanis, hogy ha a dinamikus relacionista szemléletnek igaza van, akkor nincs semmilyen társadalmi, gazdasági és hatalmi struktúra bebetonozva, még az sem, ami eddig szinte soha nem látott léptékekben uralja és rendezi az életünket az egész bolygón. Ám nem pusztán erre a távoli és történelmi léptékú reményre támaszkodhatunk, mert még annak tudatában is sokat jelent a problémák felismerése, hogy végleges megoldásuk valószínúleg csak globálisan és a társadalom számos alrendszerében eszközölt komplex beavatkozással lehetséges. Ám amíg ez meg nem történik meg, addig a szociális szférának megkerülhetetlen ártalomcsökkentő szerepe lesz. A magyar társadalom osztályszerkezetének pontos és valid leírásából láthatjuk, hogy Magyarország félperifériás helyzetéből és társadalomszerkezetéből adódóan itt fokozottan jelennek meg azok a társadalmi problémák, amelyek egyébként az egyén személyiségének, készségeinek egészséges fejlődésére is erősen kihatnak. Épp ezért a nemzeti szuverenitás és országos politika szintjén, illetve a helyi önkormányzatiság keretei közt nem csak olyan gazdaságszerkezeti reformok, területfejlesztési intézkedések mellett lesz nyomós érv a könyv, amelyek mérsékelhetnék vagy legalább kedvezőbb irányba terelhetnénk Magyarország globális kitettségét, illetőleg javíthatnák a tőkés 
világrendszerben elfoglalt pozícióját, hanem az ártalomcsökkentésben kiemelkedő szerepet játszó szociális szféra fokozottabb támogatása mellett is. Így természetesen az ott dolgozó és különleges bánásmódot igénylő személyekkel foglalkozó szakemberek mainál jóval nagyobb anyagi- és erkölcsi megbecsülését, munkakörülményeik és eszközkészletük kiemelt fejlesztését indokolnák Éber eredményei.
A könyvet azoknak ajánlanám, akik őszintén szembe akarnak nézni Magyarország félperifériás viszonyainak rendkívül komplex okaival, s a fecsegő felszín és látszatproblémák helyett inkább azt a fájdalmas tudást és keserú pirulát választják, aminek a lenyelése talán eggyel közelebb visz a magyar osztályszerkezet polarizálódásából fakadó szenvedéseinek csökkentéséhez. 